\title{
Preliminary Exploration on the Teaching Reform of "Aquatic Microbiology"
}

\author{
Zexiao Yang ${ }^{a^{*}}$, Yin Wang ${ }^{b}$, Xueping Yao ${ }^{c}$ and Qiumei $X u^{d}$ \\ Sichuan Agricultural University, Chengdu China, 611130 \\ ayzxyang2003@126.com, ${ }^{\text {byaanwangyin@tom.com, }{ }^{c} 13643 @ \text { sicau.edu.cn, }{ }^{d} 363825579 @ q q . c o m}$ \\ ${ }^{*}$ Corresponding Author
}

Keywords: Aquatic microbiology; Teaching reform; Exploration; Study; Analysis

\begin{abstract}
To improve the teaching quality of "aquatic microbiology" course. The teaching reform exploration of aquatic microbiology was carried out in recent 5 years and summarized, which including grasping the course nature of "aquatic microbiology" by means of aquaculture professional training program, revising and improving the syllabus based on the social needs of the industry, determining the teaching content, optimizing teaching methods and improving the course evaluation system on the basis of the students learning-basic situations. The results showed that the course teaching reform was benefit for the improvement of the teaching quality and had good teaching effect with an attendance rate of above $95 \%$, teaching satisfaction online evaluation above $99 \%$ and the course examination pass rate $100 \%$ every year. All these suggested that based on the needs of social development, to adhere to the dominant position and role of teachers, follow the rules of education and set up the scientific quality view is the necessary condition for the success of the reform of higher education and teaching.
\end{abstract}

\section{Introduction}

Education is the cornerstone of national rejuvenation and social progress, is the fundamental way to improve the quality of the people and promote the all-round development of people [1]. Along with the deepening of economic globalization and the rapid progress of science and technology, the increasingly fierce competition for talent. In addition, China is in the critical stage of economic, political, cultural and social development, the population, resources and environmental pressures are increasing; the transformation of economic development mode is accelerating. This has brought serious challenges and challenges to China's education, also brings rare opportunities for development, especially for the higher education of China, which is responsible for the training of senior professionals, the development of science and technology, and the promotion of socialist modernization.

Since the end of the 1990s, after the expansion of the national higher education schools, the quality of our national culture has been improved significantly, and the level of educational structure has been optimized. However, China's education is still not fully adapted to the national economic and social development. How to guarantee and improve the quality of personnel training through the development of education to meet the needs of social and economic sustainable development has become an important issue in the development of higher education in China. Education must be developed, but reform is essential [1]. The "national long-term education reform and development plan (2010-2020)" (hereinafter referred to as the "education plan") promulgated in 2010 in China and " the undergraduate teaching quality and teaching reform project" implemented in 2011 have become China's higher education teaching reform guidance and basis. The teaching reform of teaching content, method and means has become an important research project of educational reform and innovation [2-5]

"Aquatic microbiology" is a branch of Microbiology, which has been developed gradually since it was applied in aquaculture. It take the research of relationship between aquaculture development mainly and Microbiology in theory and technology as the main content [6]. This course is a professional basic course of aquaculture, aquatic disease control, aquaculture (Education) and so on, 
It not only plays an important role in the study of related courses in the later period, but also has a strong practical significance after graduation. In order to improve the students' practical ability and training quality, we have carried on the reform and exploration of teaching outline, teaching content, teaching method and performance evaluation system etc. based on the previous curriculum construction and combined with the actual situation of the teaching work in recently 5 years. This paper gives a brief summary of the exploration and achievement of teaching reform in recent years to provide some reference for the reform of higher education in China.

\section{Teaching Reform}

Syllabus Revision and Improvement of Teaching Contents. Based on the Investigation of the demand for student knowledge ability of aquaculture related majors in aquaculture industry the student's work situation and the postgraduate student study performance, the teaching syllabus was revised and teaching content was improved.

Syllabus Revision. According to the "People's Republic of China higher education law" sixteenth article on undergraduate education academic standards-It should enable students to master the specialty basic theory, basic knowledge, master the basic skills, professional knowledge and necessary methods, basic ability in practical work and research in the fields of work. Not only focus on the unity of knowledge and practice, but also distinguish between professional education, and according to the nature of basic discipline and applied discipline of "aquatic microbiology", It has been listed as a basic course in the professional training program, which is adjusted from the 5-6 semester to the 3-4 semester, with a total of 3.5 credits, a total of 56 hours, including the theoretical hours increased from 34 to 36-38 hours, experimental class hours of 18 hours. So that the theoretical study and experimental skills training can be taken into account. Meanwhile, According to the curriculum and learning situation of students, the present situation of domestic and foreign production practice and the scientific research progress the theory teaching syllabus and experiment syllabus of the course were both revised.

Teaching Content Improvement and Teaching Materials. Because there is no national planning materials and experimental teaching guide book for this course, we choose the higher agricultural colleges and universities material "the aquatic microbiology" which approved by the Teaching Committee of the national higher agricultural colleges and universities as the theory teaching material. At the same time, referring to the "experimental instruction of Veterinary Microbiology", our experimental teaching materials was improved to form the experimental teaching materials of "the experimental guidance of aquatic microbiology".

According to the limited teaching hours, the full understanding of students' poor professional knowledge basis, and overall "biochemistry", "aquatic animal diseases" and other related teaching contents, the teaching contents of theory teaching and experiment teaching were determined by the teaching and research group. In the aspect of theoretical teaching, we emphasizes the basic knowledge of microbiology and immunology, it not only avoids the repetition of the teaching content, but also lays a good foundation for the following courses. In the aspect of experiment teaching, it involves a comprehensive skill training program, including experimental notes, medium production and sterilization technology, bacteria isolation and identification technique(Separation and purification of bacterial culture, biochemical characteristics and physiological tests, staining and drug sensitive test ), immunology technique (agar diffusion test and plate agglutination test), and the classical experimental technique of virus hemagglutination assay and hemagglutination inhibition test(HA-HIA) etc. 4 aspects.

\section{Optimizing Teaching Methods and Improving Teaching Efficiency.}

Giving Full Play to the Advantages of Multimedia Teaching. With the development of the research of various disciplines, and the advanced technical methods and research results are emerging, the content of many textbooks is also increasing, the content of many textbooks is also increasing, that brings challenges to the efficiency of traditional teaching methods. We have built 
and perfected the multimedia teaching materials of the theory teaching and experimental teaching, and implement the multimedia teaching instead of the traditional teaching methods of writing. This not only ensures the teaching content, saves the teaching hours, but also can teach more new teaching contents, and the multimedia courseware through graphics, animation, images, text and video materials will process some abstract theory and time-consuming experimental project vivid and concrete. Meanwhile, the courseware were uploaded to the campus network for students to learn online or download in order to preview before class and review after class, this laid the foundation for improving the quality of teaching.

Flexible Arrangement of Teaching Content and Teaching Hours, Strict Quality Control. To save the teaching hours and improve the systematicness and acceptability of the knowledge, we do not mechanically copy textbooks in theoretical teaching, but classified the bacteria, fungi, viruses, and other microorganisms in different chapters in the textbook into microbial morphology, physiological and biochemical, genetic variation, classification and nomenclature, control technology, aquatic micro ecology and Immunology " systematically for teaching. For the experiment teaching, the comprehensive skill training program was divided into experimental notes, medium production and sterilization technology, bacteria isolation technique, bacteria identification technique, immunology technique, and the HA-HIA for 6 lectures, 3 hours per lecture, the implementation of the "practice-like" experimental teaching, to gather "parts into a whole "effect. The experimental teaching of different majors in higher education is an important part of teaching activities, which can not be replaced by the theoretical teaching, which also directly affects the quality of personnel training in colleges and universities [7,8]. According to the students "zero knowledge based" learning situation, the standard demonstration operation of teachers is the key and foundation of students' skill training. The experimental teaching mode of "strict demonstration" and "strict training" was taken to standardize the operation training and deepen the students' understanding of knowledge.

Contacting with production practice and the introduction of teaching invention. Combination of production, contact with some of the animal epidemic or veterinary public health events, and some teaching invention product materials (see Fig. 1 and Fig. 2)were introduced in the process of teaching, and achieved the purpose of improving students' learning motivation and strengthening innovation consciousness.

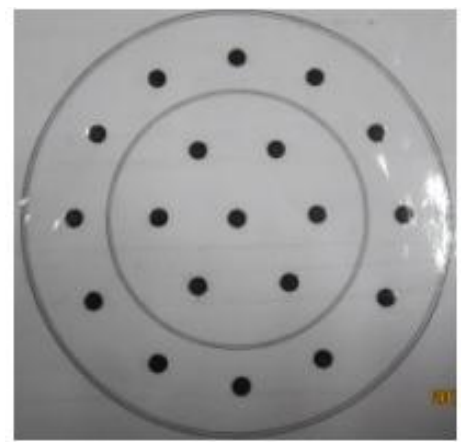

Figure 1. Drug sensitivity test placement mold products (patent ZL201620143871.3)

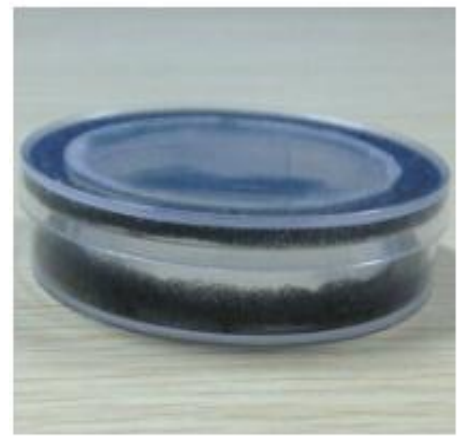

Figure 2. Double agar diffusion test kit (patent ZL201520239881.2) 
Optimizing Course Evaluation System. In order to evaluate and grasp the actual situation of students' learning and correct learning attitude, we changed the "Examination paper assessment" as the final curriculum assessment of the traditional way, and carried out the comprehensive evaluation system. The course scores was divided into test paper scores $(60 \%)$, attendance $(5 \%)$, and grade classroom training $(10 \%)$, experimental teaching achievement $(20 \%)$ and other areas $(5 \%)$. On the one hand, changed the "assault" exam error learning ideas of some students, On the other hand, through attendance and occasional classroom tests for class supervision, to correct the "crossing course selection" opportunistic credits ideas of some students.

\section{Results and Effects}

Through the reform and exploration of the teaching of aquatic microbiology in the past 5 years, the course nature was determined in the training program, the curriculum teaching outline was improved and teaching content and teaching methods were optimized, as well as the optimization of the performance evaluation system. As a result of the reform and exploration, the teaching effect is obviously improved, the attendance rate of each teaching activity is more than $95 \%$, teaching satisfaction online evaluation were above $99 \%$, and the course examination pass rate was $100 \%$ every year. Especially in the teaching process, the number of students who ask questions actively increased significantly compared with before 2010. All of these results show that the students' interest and initiative in the learning of professional knowledge had been aroused and mobilized, and the reform and exploration of aquatic microbiology was successful. Also worth mentioning is that, whether in the practice of graduation thesis or graduate student learning process students are very familiar and skilled with the operation of microbiology, and there were some graduates who from work call to communicate ideas about the establishment of a company's microbiology laboratory every year, this is very encouraging.

\section{Discussion and Conclusion}

In recent years, with China's "higher school undergraduate teaching quality and teaching reform project" full implementation, and the popularization of network education and information technology, a variety of teaching resources to enrich, the traditional classroom teaching methods are challenged. Many educators have done a lot of experiments and explorations on Teaching Reform in different fields [2-5]. There have been a lot of innovative teaching models and teaching methods, Such as heuristic teaching, inquiry teaching, scientific innovative oriented teaching[9], project teaching[10],Massive open online course[11], Flipped Class Model[12] etc. Some have achieved a certain effect. Then a key problem arises, to improve the quality of teaching, how to reform the teaching of the course? We believe that the correct understanding of the connotation of "teaching" and "teachers post" is the premise of the development and reform of education and teaching. The connotation of "teaching" includes at least three meanings. Firstly, from the perspective of humanism, it means "teacher" and "student". Secondly, from the perspective of activity, it is "teaching" and "learning"". Thirdly, from the dialectical perspective view, it means "Teaching benefits teachers as well as students" and dialectical unity of "teaching" and "learning" of the two. On the one hand, teachers from the students, "it is never too late to learn ", On the other hand, knowledge comes from production practice, through scientific research in-depth verification, sublimation theory, and then improve and serve the production practice, It is the current development direction of higher education in China - the industry-university-research cooperation, This in the "People's Republic of China higher education law" thirty-first article also has the relevant provisions" Colleges and universities should focus on cultivating talents, carry out teaching, scientific research and social services, and ensure the quality of education and teaching to meet the standards set by the state.". For the concept of "teachers post", whether it is according to the ancients interpretation of teachers " preaching, tuition, eliminating confusion ", or provisions in the outline of "educational planning" -"Taking the student as the main body, taking the teacher as the leading factor, giving full play to the initiative of the students, promoting the healthy growth of the 
students as the starting point and the end result of all the work in the school.". all of them embody the leading role of teachers in education and teaching. Education plans, teacher centered, Good education needs to have a good teacher [1]. So it can be said, although the students are the main body of learning, but the dominant position and role of teachers should not be ignored and weakened in the process of education or in the development and Reform in Education. It is not difficult to find out from the successful cases of teaching reform that the teachers' leading function(or the amount of teacher work) are strengthened after the successful teaching reform, although the characteristics of various teaching reform models or methods are different, even some of the surface seems to weaken the appearance of teachers.

There is every reason to believe, as long as under the guidance of the spirit of the "education plan", for the needs of the community, adhere to the "talent training" as the center, fully embody and play the leading role of teachers, follow the rules of education and establish the scientific quality view, to carry out education and teaching reform according to the characteristics of different specialties and courses, it can improve the quality of education and promote the healthy development of Education.

\section{Acknowledgements}

This study was supported by Grants from Research project of educational reform in Sichuan Province (2014-156-173), Teaching reform of Animal Medicine College of Sichuan Agricultural University (DY201415). Qiumei Xu should also be considered as first authors, Corresponding author: Yin Wang, Zexiao Yang.

\section{References}

[1] Information on http://edu.sina.com.cn/1/2010-07-30/ 0811191352.shtml(In Chinese)

[2] F. Zhou, Taking the student as the main body to innovate the talent training mode, China Higher Education, Vol.8(2011) No.1, p.32-33. (In Chinese)

[3] B. Qu, T. Liu, Innovating teaching management and improving the quality of personnel training, China Higher Education, Vol.8(2011) No.1, p. 39-44. (In Chinese)

[4] X.L. Jia, Z.Z. Zhu and M.J. Zhang, Discussion on teaching reform of veterinary regulations in agricultural colleges and universities, Heilongjiang Animal Science and Veterinary Medicine, Vol.15(2011) No.8, p.184-186. (In Chinese)

[5] Z.X. Yang, Y. Wang, X.P. Yao, K.Y. Wang, Z.W. Xu and L. Zhu, Exploration and experience of teaching reform of Animal Quarantine Technology, Heilongjiang Animal Science and Veterinary Medicine, Vol.427(2013) No.4, p.158-160. (In Chinese)

[6] K.Y Xiao and C.F. Chen: Aquatic microbiology, first ed. (Agricultural Press China, Beijing, 2009.), p.4 (In Chinese)

[7] J.N. Liu, X.J. Pan and X.D. Wang, Practice of experimental teaching research and Reform, Experimental Science and Technology, Vol.9(2011) No.4, p.154-156. (In Chinese)

[8] S.Q. Zhang and L. Zhang, Research on the new teaching method of Engineering Specialty in Colleges and Universities, Experimental Science and Technology, Vol.9(2011) No.4, p.62-63. (In Chinese)

[9] M. Liu, H. P. Cao and J. Zhou, Exploration and Research on "innovative" electrical experiment teaching mode, Experimental Science and Technology, Vol.9(2011) No.4, p.79-81. (In Chinese)

[10]H. Wang, J.Y. Liu and A. Chen, The application of project guidance mode in the teaching of electrical and electronic experiment, Experimental Science and Technology, Vol.9(2011) No.4, p.74-78. (In Chinese) 
[11]Q.J. Yan, Research development of domestic MOOCs, Library Theory and Practice, Vol.1 (2016) No.3, p.19-24. (In Chinese)

[12]L.M. Dong and B.C. Jiao, Study on Application of teaching model based on the concept of flipped class, E-education Research, Vol.255 (2014) No.1, p.108-120. (In Chinese) 